\title{
ADVANCES IN INTEGRATED TICK MANAGEMENT RESEARCH FOR AREA-WIDE MITIGATION OF TICK- BORNE DISEASE BURDEN
}

\author{
A. A. PÉREZ DE LEÓN ${ }^{1}$, R. D. MITCHELL III ${ }^{1}$, R. J. MILLER ${ }^{2}$ \\ AND K. H. LOHMEYER ${ }^{1}$ \\ ${ }^{1}$ USDA-ARS, Knipling-Bushland U.S. Livestock Insects Research Laboratory and \\ Veterinary Pest Genomics Center, 2700 Fredericksburg Road, Kerrville, Texas \\ 78028,USA; Beto.PerezdeLeon@ARS.USDA.GOV \\ ${ }^{2} U S D A-A R S$, Cattle Fever Tick Research Laboratory and Veterinary Pest Genomics \\ Center, 22675 N. Moorefield Road, Edinburg, Texas 78541, USA
}

\begin{abstract}
SUMMARY
In some parts of the world, ticks are the most dangerous animals followed by mosquitoes as ectoparasites and vectors of infectious agents, causing morbidity and mortality in domestic animals including wildlife and humans. The majority of tick-borne diseases are zoonotic. The global importance of ticks and tickborne diseases in veterinary medicine and public health keeps growing. Some ticks are invasive and transmit pathogens causing transboundary diseases of high consequence for populations of domestic animals and humans. Integrated management pursues the optimized use of compatible methods to manage pests in a way that is safe, economically viable, and environmentally sustainable. The area-wide approach augments and expands the benefits of integrated pest management strategies. Issues challenging the implementation, adoption, and viability of area-wide tick management programmes include funding and socio-political aspects, the availability of support systems related to extension and veterinary services, and stakeholder involvement. Management strategies need to adapt and integrate novel technologies to decrease significantly the use of pesticide and address the complex problem of ticks and tick-borne diseases effectively. Applying the One Health concept, the strategy to optimize health outcomes for humans, animals, and the environment, facilitates research on the interplay between climate, habitat, and hosts driving tick population dynamics. It enhances our understanding of the epidemiology of tick-borne diseases and advances their management. This overview of research for adaptive area-wide integrated management concentrates on ticks affecting livestock. Examples focus on Rhipicephalus microplus (Canestrini) as one of the tick disease vectors most studied worldwide. Highlights of integrated management research for ticks
\end{abstract}

J. Hendrichs, R. Pereira and M. J. B. Vreysen (eds.), Area-Wide Integrated Pest Management: Development and Field Application, pp. 251-274. CRC Press, Boca Raton, Florida, USA. (C) 2021 U. S. Government 
of public health importance transmitting zoonotic diseases are reviewed to document opportunities for integrated control that mitigate the health burden of tick-borne diseases on humans, domestic animals, and wildlife. Implementation of the research conducted so far is needed to accelerate advancements in areawide management of tick populations that can be applied to improve prevention across tick-borne diseases, while decreasing pesticide application and contributing to vector control globally.

Key Words: Acari, Rhipicephalus annulatus, Rhipicephalus microplus, babesiosis, ectoparasites, disease vectors, tick-borne pathogens, acaricides, resistance, cattle fever tick reservoirs, livestock vaccination, areawide tick management, integrated tick-borne disease prevention, One Health, global change, invasive

\section{INTRODUCTION}

In some parts of the world, ticks (Acari) are the most dangerous animals followed by mosquitoes as ectoparasites and vectors of infectious agents causing morbidity and mortality in domestic animals, wildlife and humans (Ahmed et al. 2007; Socolovschi et al. 2008; Heyman et al. 2010; Barker et al. 2014; Paddock et al. 2016). Approximately $80 \%$ of the cattle in tropical and subtropical regions of the world are affected by economically important ticks and tick-borne pathogens (McCosker 1979; de Castro 1997). In addition, estimates indicate that Lyme disease and other diseases caused by tick-borne pathogens could burden over $30 \%$ of the global human population by 2050 (Davidsson 2018; Sakamoto 2018). Most tick-borne diseases affecting people are zoonotic because they can be transmitted from wild and domestic animals to humans through the bite of an infected tick (Lorusso et al. 2016; OjedaChi et al. 2019).

Life history traits afford ticks considerable importance as pests and vectors of pathogens. Ticks are ancient arthropods that parasitize vertebrate hosts by feeding on blood to be able to complete their life cycle (Mans et al. 2011; Peñalver et al. 2018). Tick-borne pathogens include protozoa, bacteria, and viruses that co-infect their vectors and hosts (Brites-Neto et al. 2015; Talactac et al. 2018; Wikel 2018). Being local specialists and global generalists in their host associations underlie the global distribution of ticks and their ability to adapt to diverse environmental niches (McCoy et al. 2013; de la Fuente et al. 2015b; Beati and Klompen 2019).

There are ca. 920 described tick species in the world, but the diversity of ticks remains to be fully established (Dantas-Torres 2018; Mans et al. 2019). The so-called hard ticks belong to the Ixodidae family that have a sclerotized scutal plate in their dorsum (Sonenshine and Roe 2014). By comparison, soft ticks in the family Argasidae lack the scutum and have a flexible leathery cuticle (Uspensky 2008). Depending on the tick species, the parasitic larva, nymph, and adult stages are completed in one, two, or three hosts (Estrada-Peña 2015). After blood-engorged, females that mated on the host, then drop off and lay their eggs in the environment (Needham and Teel 1991).

Some ticks are invasive and transmit pathogens causing transboundary diseases of high consequence for populations of domestic animals and humans (Minjauw and McLeod 2003; Burridge 2011; Fernández and White 2016; Higgs 2018; Robles et al. 2018; Spengler et al. 2018). 
Non-anthropogenic and anthropogenic factors associated with global change, including environmental disturbance and climate variability (Benavides Ortiz et al. 2016; Ogden and Lindsay 2016; Singer and Bulled 2016), increased international trade and travel (Abdullah et al. 2018; Hansford et al. 2018), and the wildlifelivestock-human interface (Gortazar et al. 2015), have increased tick densities resulting in a greater prevalence of tick-borne disease cases (Gasmi et al. 2018; Rasi et al. 2018; Sonenshine 2018). Furthermore, several of the newly discovered tickborne microbes are pathogenic to humans and domestic animals (Mansfield et al. 2017; Harvey et al. 2019).

Discoveries by Smith and Kilborne (1893), documenting that Rhipicephalus annulatus Say was a vector of Babesia bigemina (Smith et Kilborne 1893), were important in the history of science by showing for the first time that arthropods can transmit pathogens to their hosts (Smith and Kilborne 1893; McCosker 1993; Egerton 2013).

Smith and Kilborne (1893) suggested the destruction of all $R$. annulatus infesting cattle to treat the disease after noting that outbreaks of bovine babesiosis, caused by $B$. bigemina, also known as redwater or cattle tick fever, and considered to be the most economically important arthropod-borne disease of cattle worldwide (Bock et al. 2008), could not happen without tick parasitism. In retrospect, this research association is an example of the One Health concept described below because T. Smith was a physician and F. L. Kilborne a veterinarian (Schultz 2008).

By 1893, cattle in the USA, Australia, and parts of Africa were already immersed in dipping vats containing various chemical pesticides active against ticks commonly referred to through time as tickicides, ixodicides, or acaricides, to manage infestations associated with what we now know are tick-borne diseases (Angus 1996; George 2000; Alonso-Díaz et al. 2006). The term acaricide used here refers to pesticides used to kill ticks of veterinary and public health importance following the conventions of most literature published on the topic. Vaccination against the pathogen is another approach to prevent and control tick-borne diseases. Attempts by Connaway and Francis (1899) to protect cattle from bovine babesiosis were among the first ones to vaccinate against a tick-borne disease. Several vaccines are commercially available in Europe to prevent tick-borne encephalitis (Riccardi et al. 2019). Nevertheless, the need remains for improved and cost-effective vaccines to prevent tick-borne diseases affecting humans (Šmit and Postma 2016; Reece et al. 2018), as well as domestic animals (Perry 2016; Pruneau et al. 2018; Suarez et al. 2019).

Effective and safe tick and tick-borne disease management requires integration of rational tactics involving multiple biological, chemical, physical and vaccine technologies on and off hosts. They can include the judicious application of safer acaricides to address the concerns with chemical treatments (de Meneghi et al. 2016; Pfister and Armstrong 2016; Ginsberg et al. 2017).

Here we review highlights of integrated management research for ticks of public health importance transmitting zoonotic diseases to document opportunities for combined interventions that mitigate the health burden of tick-borne diseases, benefitting humans, domestic animals, and wildlife (Drexler et al. 2014; Khamesipour et al. 2018; Wang et al. 2018). 


\section{AREA-WIDE TICK MANAGEMENT AND RESEARCH}

\subsection{Research Needs for Integrated Area-wide Tick Management}

This overview concentrates on research to enable the area-wide integrated management of livestock ticks. Examples focus on Rhipicephalus microplus (Canestrini), a one-host tick commonly known as the Asian blue tick or southern cattle fever tick, originally described as Haemaphysalis micropla by Canestrini (1887). It is one of the ticks most studied worldwide as it is a vector of B. bigemina and B. bovis Babes causing bovine babesiosis (Pérez de León et al. 2014b; Gray et al. 2019), and Anaplasma marginale Theiler causing anaplasmosis (Atif 2015). R. microplus is an invasive species considered the most economically important ectoparasite of livestock globally (Rodríguez-Vivas et al. 2017a; Betancur-Hurtado and Giraldo-Ríos 2018; Sungirai et al. 2018).

The synonym concepts of area-wide integrated pest management, system-, or areawide pest management, convey the need for research that can be applied to address the complex problem with ticks and tick-borne diseases (Brévault and Bouyer 2014; Pérez de León et al. 2014a; Bourtzis et al. 2016). Efficiency and cost-effectiveness are fundamental to area-wide approaches dealing with societal problems for centuries, including those related to tick disease vectors (Hendrichs et al. 2007; Koul et al. 2008; Shepard et al. 2014).

The goal of integrated pest management is to optimize the use of compatible methods in a way that is safe, economically viable, and ecologically sustainable (Jørs et al. 2017; Mullens et al. 2018). The area-wide approach augments and expands to the population level the benefits of integrated pest management strategies. Tick suppression and eradication can be considered as a continuum in the spectrum of areawide strategies to manage tick-borne diseases. Approaches for sustainable area-wide control of tick populations recognize the need for translational research to develop new and improved technologies before eradication can be contemplated (Bram and Gray 1979; Pegram et al. 2007; Pluess et al. 2012; Suckling et al. 2014). A common theme for these strategies is the continued need to re-evaluate our understanding of tick biology and ecology (Tatchell 1992; Schmidtmann 1994; Esteve-Gassent et al. 2016; Canevari et al. 2017).

\subsection{Unifying Area-wide Tick-borne Disease Mitigation and One Health through Integrated Tick Management Research}

Applying the One Health concept, i.e. a strategy to optimize health outcomes for humans, animals, and the environment, facilitates research on the interplay between climate, habitat, and hosts driving tick population dynamics. It enhances our understanding of the epidemiology of tick-borne diseases and advances their management (Dantas-Torres et al. 2012; Vayssier-Taussat et al. 2015; Laing et al. 2018; World Bank 2018) (Fig. 1). 


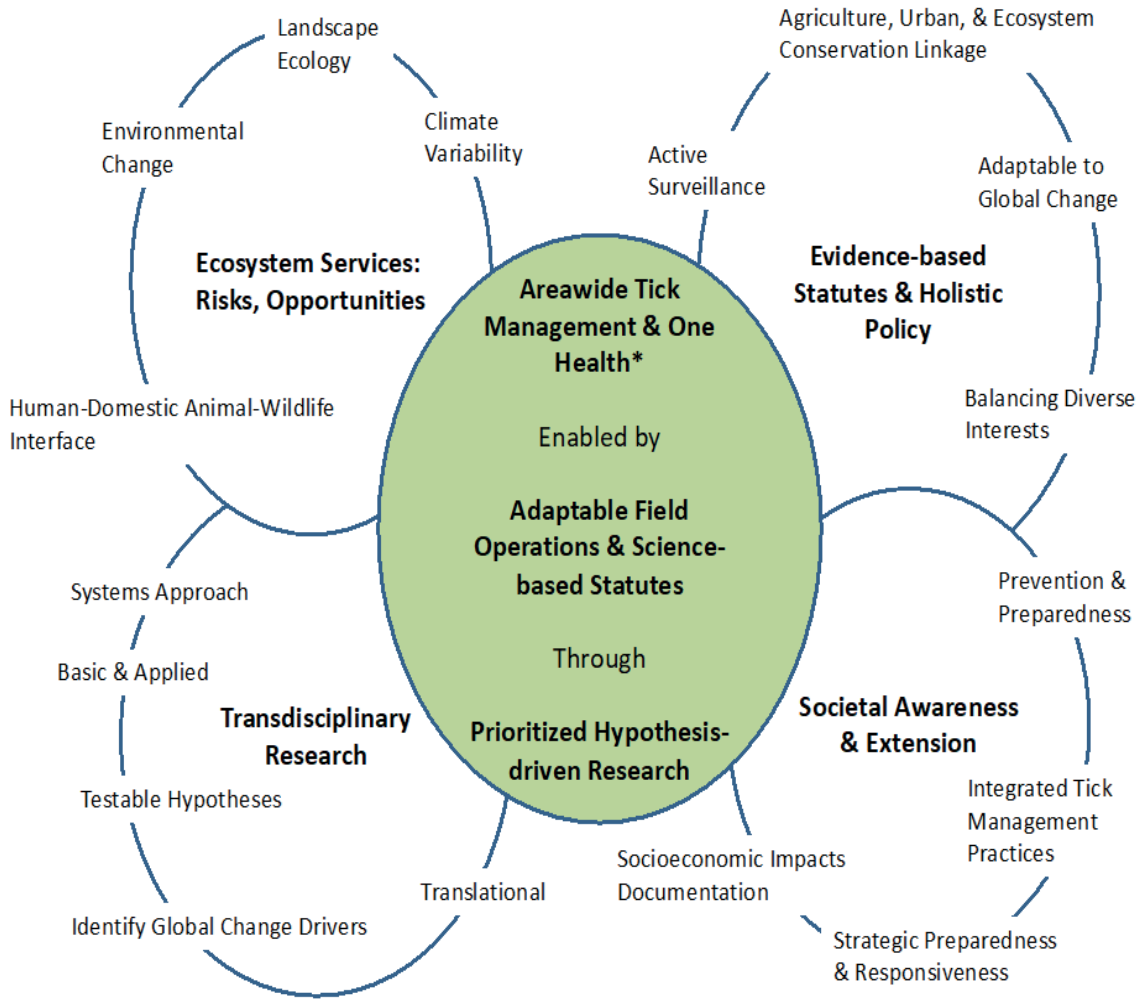

Figure 1. Suggested research and implementation framework toward sustainable area-wide integrated tick management to prevent tick-borne diseases in the context of global change and the One Health approach (*adapted from Pérez de León et al. 2012).

Previous efforts indicate socio-economic and cultural aspects must be considered in the planning and evaluation of area-wide tick management programmes (Pegram et al. 2000; Hendrichs et al. 2007; Rushton 2009; Mutavi et al. 2018). This can be done using algorithms to select area-wide tick management interventions where the evidence thus generated is used to enhance model predictions that improve area-wide tick management practices (Sutherst et al. 2007; Wang et al. 2017).

Ideal characteristics of technologies for broad acceptability and integrated use against ticks include low cost, minimal effort required for their application, spectrum of efficacy covering as many tick species as possible, and residual activity (Graf et al. 2004; Playford et al. 2005; Eisen and Eisen 2018). Control technologies can target ticks on or off the host. 
In addition to acaricides, parasitoids and predators, alteration of the environment, and physical methods were identified for off-host tick control (FAO 1961). The Sterile Insect Technique, botanical repellents and acaricides, host resistance, pheromonebased approaches, and anti-tick vaccines are potential approaches to be integrated for the control of ticks infesting hosts (IAEA 1968; Ghosh and Nagar 2014; de Oliveira Filho et al. 2017). However, reducing to practice the integration of acaricides with other technologies in area-wide tick management remains to be fully accomplished (Jonsson 2004; de la Fuente et al. 2015a).

Adequate protocols and implementation research to evaluate technologies under field conditions are needed to generate the scientific evidence required to justify the investment of resources for area-wide tick management programmes (Piesman and Eisen 2008; Bautista-Garfias and Martínez-Ibañez 2012).

The adoption and viability of these programmes require attention to resource allocation and socio-political aspects, the availability of support systems related to extension and veterinary services, and the engagement of stakeholders (Walker 2011; Estrada-Peña and Salman 2013; Bugeza et al. 2017; Kerario et al. 2018; Mihajlović et al. 2019).

\subsection{Alternatives to Acaricide Use and Strategies to Solve Resistance to Chemical Treatments}

Chemical treatment practices in livestock production systems are under scrutiny because of the impact acaricides and endectocides like ivermectin have on public health, the environment, and the international trade of livestock and animal products (González and Hernández 2012; Arisseto-Bragotto et al. 2017; Miraballes and RietCorrea 2018).

Intense chemical treatment of infested hosts exerts strong selection pressure for acaricide resistance among tick populations (Guerrero et al. 2014b; de Miranda Santos et al. 2018; Rodríguez-Vivas et al. 2018). Resistance to multiple classes of acaricides keeps spreading among tick populations due to intensive application (Miller et al. 2013; Cuore et al. 2015; Klafke et al. 2017b; Vudriko et al. 2018).

Acaricide resistance resulting from chemical treatment intended to control other parasites can exacerbate the problem with ticks and tick-borne diseases (Foil et al. 2004). Ivermectin used to treat gastrointestinal parasitic infections in cattle simultaneously infested with $R$. microplus selected for resistance due to exposure of the ticks to sublethal doses of that endectocidal drug (Alegría-López et al. 2015). $R$. microplus ranks sixth among the arthropods most resistant to pesticides in the world (Whalon et al. 2008).

Resistance to organophosphates, pyrethroids, amitraz, and ivermectin was reported in the brown dog tick, Rhipicephalus sanguineus sensu lato (Latreille) (Klafke et al. 2017a, Rodríguez-Vivas et al. 2017b). 
Amblyomma cajennense s.l. (Fabricius) is another three-host tick that was found to be resistant to organophosphates and amitraz in Mexico (Alonso-Díaz et al. 2013). Different acaricide resistance profiles have been reported for two- and three-host tick species parasitizing cattle in South Africa (Ntondini et al. 2008). Widespread resistance to commonly used acaricides has not been reported for other important vectors of zoonotic tick-borne diseases parasitizing humans in the USA and Europe (Coles and Dryden 2014; EMA 2018).

Strategies to diminish acaricide use in domestic animals need to consider the concept of integrated parasite/vector management to maximize the contributions of veterinary public health towards sustainable development (Henrioud 2011; Scasta 2015; Narladkar 2018).

The commercial availability of a technology based on the recombinant protein Bm86 in the 1990s to vaccinate cattle against $R$. microplus represented a significant research achievement towards sustainable area-wide tick management (de la Fuente et al. 2007; Willadsen 2008). Integrating the use of a Bm86-based anti-R. microplus vaccine in an area-wide management programme confirmed that this approach decreases the frequency of acaricide treatments and diminishes the amount of chemicals used to control infestations, while reducing tick-borne cases in a costeffective manner (de la Fuente et al. 1998; Redondo et al. 1999; Valle et al. 2004; Suarez et al. 2016). This is a rational and environment-friendly approach to manage $R$. microplus populations that are resistant to multiple classes of acaricides. Various research efforts to develop vaccines against other hard and soft ticks and the application of an anti-tick vaccine to protect humans, domestic animals, and wildlife from tick-borne diseases are ongoing (Évora et al. 2017; Almazán et al. 2018; de la Fuente et al. 2018).

Collaborative partnerships established to improve efficiencies in the research and development process of those anti-tick vaccines are examples of how global efforts could fully realize the benefits of international cooperation to enable breakthroughs allowing the adaptation of area-wide tick management practices to protect livestock and humans from tick-borne diseases (Sprong et al. 2014; Schetters et al. 2016; Rodríguez-Mallon et al. 2018; Ybañez et al. 2018). These joint international efforts have also resulted in the sequencing the genome of $R$. microplus to mine the information therein for the innovation of management technologies (Barrero et al. 2017).

Integrative taxonomy studies reinstated Rhipicephalus australis as a species and revealed that $R$. microplus consists of 3 clades (Estrada-Peña et al. 2012; Roy et al. 2018). Furthermore, some of the new microbes found to be associated with $R$. microplus are known livestock pathogens, while the pathogenicity of others remains unknown (Andreotti et al. 2011; Biguezoton et al. 2016; de Souza et al. 2018; de Oliveira Pascoal et al. 2019). 


\section{RESEARCH FOR ADAPTIVE AREA-WIDE TICK MANAGEMENT}

\subsection{Eradication Efforts Exemplify Challenges with Tick Management in the Context of Global Change}

In 1906 the USA established the Cattle Fever Tick Eradication Program (CFTEP) to eliminate bovine babesiosis by exterminating the tick vectors of the disease based on the scientific evidence generated by the research of Curtice (1891) and Smith and Kilborne (1893) (Curtice 1910). In the context of complex socio-economic dynamics (Strom 2010), the CFTEP efforts has involved cooperation between federal, state governments, and the livestock industry. In 1943, with the exception of a Permanent Quarantine Zone along the Rio Grande in south Texas at the border with Mexico, the USA was declared free of the tick vectors (Graham and Hourrigan 1977).

The cattle fever ticks $R$. annulatus and $R$. microplus remain widespread in Mexico (Bautista-Garfias and Martínez-Ibañez 2012), and incursions from Mexico into the free zone, which comprises the rest of the continental USA, are buffered by the Permanent Quarantine Zone (George 1989; Klassen 1989). After 112 years of operations, events related to global change, such as land use changes, livestockwildlife interface intricacies, and climate variability, complicate efforts by the CFTEP to keep the USA cattle fever tick-free (George 2008; Esteve-Gassent et al. 2014; Rutherford 2019).

A surge of cattle fever tick outbreaks in the free zone during the first decade of this century prompted a re-evaluation of the research agenda in support of the CFTEP (Pérez de León et al. 2010; Lohmeyer et al. 2011). Action was taken based on research needs in consultation with stakeholders to address the main concerns with acaricide resistance (Pérez de León et al. 2013), the role of native and exotic ungulates as cattle fever tick reservoirs (Pound et al. 2010), climate variability as a driver for the reintroduction of cattle fever ticks into the free zone (Giles et al. 2014), and a reevaluation of financial losses associated with these concerns and events (Anderson et al. 2010).

Research in support of integrated cattle fever tick eradication provides a pathway to generate scientific evidence that could be used to adapt CFTEP operations that minimize the impact of global change (Pérez de León et al. 2012). Aspects related to the mechanism of action of organophosphate acaricides allowed charging the dipping vats at $0.3 \%$ coumaphos to mitigate concerns by the CFTEP with organophosphateresistant cattle fever tick outbreak populations (Miller et al. 2005). The detection of pyrethroid resistance in cattle fever ticks infesting cattle and white-tailed deer, Odocoileus virginianus (Zimmermann), a wild ungulate species native to the Americas and a host of cattle fever ticks that is abundant in south Texas, limits treatments with permethrin by the CFTEP (Busch et al. 2014). Use of an injectable formulation of $1 \%$ doramectin was adapted by the CFTEP as an alternative eradication procedure (Davey et al. 2012). Macrocyclic lactone resistance among cattle fever tick outbreak populations has so far not been reported. 
Further studies are required to determine if research can be translated into protocols involving the use by the CFTEP of safer acaricides to treat cattle and wild ungulates (Costa-Júnior et al. 2016; Gross et al. 2017).

A device using corn as bait to attract white-tailed deer for self-treatment was developed for use by the CFTEP because white-tailed deer cannot be gathered for treatment as it is done with cattle (Pound et al. 2012). The white-tailed deer consuming corn rub against acaricide-impregnated rollers placed on the device during the hunting season and are thus treated topically, whereas corn medicated with ivermectin acting systemically to control cattle fever ticks is used to bait white-tailed deer during the off-hunting season (Lohmeyer et al. 2013). However, complex white-tailed deer behaviours and social interactions to access the bait stations and other logistical aspects limit the use of this technology in the Permanent Quarantine Zone (Currie 2013).

Impediments for cattle fever tick eradication associated with the presence of nilgai (Boselaphus tragocamelus (Pallas) in parts of south Texas, where they can coexist with cattle and white-tailed deer, further exemplify the challenges presented by the livestock-wildlife interface for area-wide tick management (Wang et al. 2016; Singh et al. 2017; Lohmeyer et al. 2018). Nilgai are introduced bovid hosts of cattle fever ticks and suspected reservoirs of B. bovis and B. bigemina with home ranges larger than white-tailed deer (Foley et al. 2017; Olafson et al. 2018). Research is underway to determine if nilgai can be attracted to sites where they would be treated against cattle fever tick infestation (Goolsby et al. 2017).

The high efficacy of the Bm86 antigen against $R$. annulatus prompted efforts to research the use of an anti-tick vaccine as part of integrated cattle fever tick eradication procedures (Miller et al. 2012). Research involved reverse vaccinology to pursue the discovery of antigens that could be formulated for use by the CFTEP with efficacy against $R$. microplus equivalent to that of Bm86-based vaccines against $R$. annulatus (Guerrero et al. 2014a). In the interim, a public-private partnership enabled the use of a Bm86-based vaccine by the CFTEP (Pérez de León et al. 2018). This was a significant event in the history of cattle fever tick eradication in the USA because federal and state statutes, more than a century old governing the CFTEP, were adapted to use the anti-tick vaccine technology. This Bm86-based vaccine was used in a research project for integrated $R$. microplus management in Puerto Rico (Wang et al. 2019).

Integrating vaccination of white-tailed deer against cattle fever ticks would complement the effects of the self-treatment bait stations described above (Carreón et al. 2012; Estrada-Peña et al. 2014). However, delivery systems remain to be refined to vaccinate free-ranging white-tailed deer against cattle fever ticks in the Permanent Quarantine Zone. 


\subsection{Research Perspectives to Mitigate Tick-borne Disease Burden Focused on Integrated Tick Management}

Applying the concept of precision agriculture and making use of newly available technologies, provides the opportunity to establish exact and targeted interventions to realize substantial savings in inputs for area-wide tick management (Urdaz-Rodríguez et al. 2015; Pérez de León 2017).

Experiments with unmanned aerial vehicles or drones showed this technology can support surveillance by the CFTEP (Goolsby et al. 2016), but it could also be integrated with remote sensing using ground-truth data for strategic cattle fever tick suppression (Phillips et al. 2014; Leal et al. 2018). Robotic technology is being adapted for tick control as well, showing potential in reducing tick densities (Gaff et al. 2015).

Precision tick management could facilitate the adoption of safer control technologies for effective area-wide campaigns. These include commercially available alternatives to the conventional use of acaricides such as acaropathogenic fungi or nematodes, and botanical acaricides, although they require further testing for adoption by the CFTEP (Thomas et al. 2017; Goolsby et al. 2018; Singh et al. 2018). Additionally, big data strategies facilitate the translation of genomic information into knowledge that can be applied to develop technologies which specifically target cattle fever ticks (Munoz et al. 2017; Brock et al. 2019).

Tick-borne diseases threaten public health in the USA. Around twenty human diseases or clinical conditions are associated with tick bites (USHHS 2018). Current trends indicate that $>75 \%$ of the vector-borne disease cases reported are tick-borne (Rosenberg et al. 2018). Among the ticks commonly found biting humans (Eisen et al. 2017), the black-legged tick Ixodes scapularis Say is known to transmit seven pathogens of human diseases (Eisen and Eisen 2018). Controlling tick populations, together with personal protection measures, reduce exposure of the public to infected ticks, which prevents tick-borne diseases (Stafford III et al. 2017; White and Gaff 2018).

A higher level of public acceptability is associated with area-wide interventions employing technologies that are safe for people, pets, and the environment (Aenishaenslin et al. 2016; Keesing and Ostfeld 2018). These include the integrated use of host-targeted devices delivering minimal acaricide quantities with broadcast application of acaropathogenic fungus, as well as white-tailed deer reduction to decrease the risk of human exposure to I. scapularis infected with Borrelia burgdorferi Johnson et al. (Telford 2017; Williams et al. 2018). Additionally, internetbased surveillance tools and citizen science participation may enhance area-wide integrated tick management practices (Pollett et al. 2017; Nieto et al. 2018; Jongejan et al. 2019). 
The detection in 2017 of Haemaphysalis longicornis Neumann, commonly known as the Asian longhorned tick, and subsequent reports of infestations in humans, domestic animals, and wildlife in the USA is a reminder of the threat posed by invasive ticks to the health of humans and other animals (Rainey et al. 2018). $H$. longicornis is a known vector of pathogens affecting humans, domestic animals, and wildlife in its native range and previously invaded areas, but it remains to be determined if it is transmitting pathogens in the USA (Beard et al. 2018).

Habitat suitability analyses indicate that $H$. longicornis could become established also in other parts of North America (Magori 2018; Hutcheson et al. 2019; Rochlin 2019). Challenges managing the spread of this Asian longhorned tick in the USA present an opportunity to apply the One Health concept where governmental agencies, academic institutions, public organizations, and private industry representing the agricultural, public health, medical, and veterinary sectors operate under a national strategy to prevent cases of H. longicornis-borne diseases in humans and other animal species.

Implementation research is needed to accelerate advancements in area-wide tick management. Achieving this goal will facilitate the adaptation and adoption of those advancements to improve prevention across tick-borne diseases while contributing to vector control globally (WHO 2017; Theobald et al. 2018; Fouet and Kamdem 2019; Petersen et al. 2019).

\section{CONCLUSIONS}

Ticks and tick-borne diseases continue to present new and emerging threats to humans, domestic animals, and wildlife. Constraints faced by the CFTEP to continue maintaining the USA cattle fever tick-free, a successful area-wide programme that has been operating in the USA since its establishment in 1906, illustrate how global change impacts area-wide tick management efforts.

Current issues are complex and need to be addressed by veterinary and public health programmes dealing with ticks and tick-borne diseases. This grand challenge requires a reassessment of strategies to manage tick populations. The One Health approach provides a framework to mitigate the health burden of tick-borne diseases on humans, domestic animals, and wildlife.

Advances in transdisciplinary scientific research present opportunities to adapt the strategy for area-wide tick management. The integration of novel technologies can decrease the use of acaricides significantly. Pilot field studies help determine the utility of integrated tick management strategies under real-life conditions. Outcomes from those pilot field studies inform decisions on the extent of interventions to prevent tick-borne diseases through improved tick population management. Progressive tick control affords flexibility to fine-tune the integration of technologies through the exchange of scientific information between stakeholders engaged in the adaptation process and provides feedback to revise the research agenda. 
Implementation research can accelerate the translation of earlier research efforts to area-wide tick management practice. It is important for scientists to also understand the socio-economic context of research. Grasping the expectations of end-users of technology is paramount to realize the common vision of improving the outcomes of tick control interventions. This process will enhance the quality of evidence delivered by scientific research. Such scientific evidence can be used to generate the support for resources to establish the capacities required for the effective management of ticks to mitigate the burden of tick-borne diseases.

\section{REFERENCES}

Abdullah, S., C. Helps, S. Tasker, H. Newbury, and R. Wall. 2018. Prevalence and distribution of Borrelia and Babesia species in ticks feeding on dogs in the UK. Medical and Veterinary Entomology 321: 14-22.

Aenishaenslin, C., P. Michel, A. Ravel, L. Gern, J. P. Waaub, F. Milord, and D. Bélanger. 2016. Acceptability of tick control interventions to prevent Lyme disease in Switzerland and Canada: A mixed-method study. BMC Public Health 16: 12-21.

Ahmed, J., H. Alp, M. Aksin, and U. Seitzer. 2007. Current status of ticks in Asia. Parasitology Research 1012: 159-162.

Alegría-López, M., R. Rodríguez-Vivas, J. Torres-Acosta, M. Ojeda-Chi, and J. Rosado-Aguilar. 2015. Use of ivermectin as endoparasiticide in tropical cattle herds generates resistance in gastrointestinal nematodes and the tick Rhipicephalus microplus (Acari: Ixodidae). Journal of Medical Entomology 522: 214-221.

Almazán, C., G. A. Tipacamu, S. Rodríguez, J. Mosqueda, and A. Pérez de León. 2018. Immunological control of ticks and tick-borne diseases that impact cattle health and production. Frontiers in Bioscience (Landmark edition) 23: 1535-1551.

Alonso-Díaz, M., R. Rodríguez-Vivas, H. Fragoso-Sánchez, and R. Rosario-Cruz. 2006. Ixodicide resistance of the Boophilus microplus tick to ixodicides. Archivos de Medicina Veterinaria 382: 105 113.

Alonso-Díaz, M., A. Fernández-Salas, F. Martínez-Ibáñez, and J. Osorio-Miranda. 2013. Amblyomma cajennense (Acari: Ixodidae) tick populations susceptible or resistant to acaricides in the Mexican tropics. Veterinary Parasitology 197: 326-331.

Anderson, D., A. Hagerman, P. Teel, G. Wagner, J. Outlaw, and B. Herbst. 2010. Economic impact of expanded fever tick range. Agricultural \& Food Policy Center, Texas A\&M University, College Station, Texas, USA.

Andreotti, R., A. A. Pérez de León, S. E. Dowd, F. D. Guerrero, K. G. Bendele, and G. A. Scoles. 2011. Assessment of bacterial diversity in the cattle tick Rhipicephalus (Boophilus) microplus through tag-encoded pyrosequencing. BMC Microbiology 11: 6 .

Angus, B. M. 1996. The history of the cattle tick Boophilus microplus in Australia and achievements in its control. International Journal for Parasitology 2612: 1341-1355.

Arisseto-Bragotto, A. P., M. M. C. Feltes, and J. M. Block. 2017. Food quality and safety progress in the Brazilian food and beverage industry: Chemical hazards. Food Quality and Safety 12: 117-129.

Atif, F. A. 2015. Anaplasma marginale and Anaplasma phagocytophilum: Rickettsiales pathogens of veterinary and public health significance. Parasitology Research 114: 3941-3957.

Barker, S. C., A. R. Walker, and D. Campelo. 2014. A list of the 70 species of Australian ticks; diagnostic guides to and species accounts of Ixodes holocyclus (paralysis tick), Ixodes cornuatus (southern paralysis tick) and Rhipicephalus australis (Australian cattle tick); and consideration of the place of Australia in the evolution of ticks with comments on four controversial ideas. International Journal for Parasitology 4412: 941-953.

Bautista-Garfias, C., and F. Martínez-Ibañez. 2012. Experiences on the control of cattle tick Rhipicephalus (Boophilus) microplus in Mexico, pp. 205-216. In M. Woldemeskel (ed.), Ticks: Disease, management, and control. Nova Science Publishers, Inc. New York, NY, USA. 
Beard, C. B., J. Occi, D. L. Bonilla, A. M. Egizi, D. M. Fonseca, J. W. Mertins, B. P. Backenson, W. I. Bajwa, A. M. Barbarin, M. A. Bertone, J. Brown, N. P. Connally, N. D. Connell, R. J. Eisen, R. C. Falco, A. M. James, R. K. Krell, K. Lahmers, N. Lewis, S. E. Little, M. Neault, A. A. Pérez de León, A. R. Randall, M. G. Ruder, M. N. Saleh, B. L. Schappach, B. A. Schroeder, L. L. Seraphin, M. Wehtje, G. P. Wormser, M. J. Yabsley, and W. Halperin. 2018. Multistate infestation with the exotic disease-vector tick Haemaphysalis longicornis - United States, August 2017-September 2018. Morbidity and Mortality Weekly Report 6747: 1310-1313.

Beati, L., and H. Klompen. 2019. Phylogeography of ticks (Acari: Ixodida). Annual Review of Entomology 64: 379-397.

Benavides Ortiz, E., J. Romero Prada, and L. C. Villamil Jiménez. 2016. Las garrapatas del ganado bovino y los agentes de enfermedad que transmiten en escenarios epidemiológicos de cambio climático: Guía para el manejo de garrapatas y adaptación al cambio climático. Instituto Interamericano de Cooperación para la Agricultura (IICA), San José, Costa Rica.

Betancur-Hurtado, O. J., and C. Giraldo-Ríos. 2018. Economic and health impact of the ticks in production animals, pp. 1-19. In M. Abubakar (ed.), Ticks and tick-borne pathogens. IntechOpen, London, UK.

Biguezoton, A., V. Noel, S. Adehan, H. Adakal, G. K. Dayo, S. Zoungrana, S. Farougou, and C. Chevillon. 2016. Ehrlichia ruminantium infects Rhipicephalus microplus in West Africa. Parasites \& Vectors 9: 354.

Bock, R. E., L. A. Jackson, A. J. de Vos, and W. K. Jorgensen. 2008. Babesiosis of cattle, pp. 281-307. In A. S. Bowman, and P. Nuttal (eds.), Ticks: Biology, disease, and control. Cambridge University Press, New York, NY, USA.

Bourtzis, K., R. S. Lees, J. Hendrichs, and M. J. Vreysen. 2016. More than one rabbit out of the hat: Radiation, transgenic and symbiont-based approaches for sustainable management of mosquito and tsetse fly populations. Acta Tropica 157: 115-130.

Bram, R. A., and J. H. Gray. 1979. Eradication - An alternative to tick and tick-borne disease control. World Animal Review 30: 30-35.

Brévault, T., and J. Bouyer. 2014. From integrated to system-wide pest management: Challenges for sustainable agriculture. Outlooks on Pest Management 253: 212-213.

Brites-Neto, J., K. M. R. Duarte, and T. F. Martins. 2015. Tick-borne infections in human and animal population worldwide. Veterinary World 83: 301-315.

Brock, C. M., K. B. Temeyer, J. Tidwell, Y. Yang, M. A. Blandon, D. Carreón-Camacho, M. T. Longnecker, C. Almazán, A. A. Pérez de León, and P. V. Pietrantonio. 2019. The leucokinin-like peptide receptor from the cattle fever tick, Rhipicephalus microplus, is localized in the midgut periphery and receptor silencing with validated double-stranded RNAs causes a reproductive fitness cost. International Journal for Parasitology 49: 287-299.

Bugeza, J., C. Kankya, J. Muleme, A. Akandinda, J. Sserugga, N. Nantima, E. Okori, and T. Odoch. 2017. Participatory evaluation of delivery of animal health care services by community animal health workers in Karamoja region of Uganda. PLoS One 126: e0179110.

Burridge, M. J. 2011. Non-native and invasive ticks: Threats to human and animal health in the United States. University Press of Florida, Gainesville, Florida, USA.

Busch, J. D., N. E. Stone, R. Nottingham, A. Araya-Anchetta, J. Lewis, C. Hochhalter, J. R. Giles, J. Gruendike, J. Freeman, and G. Buckmeier. 2014. Widespread movement of invasive cattle fever ticks (Rhipicephalus microplus) in southern Texas leads to shared local infestations on cattle and deer. Parasites \& Vectors 7: 188.

Canestrini, G. 1887. Intorno ad alcuni Acari ed Opilionidi dell' America. Atti della Società VenetoTrentina di Scienze Naturali 11: 100-111.

Canevari, J. T., A. J. Mangold, A. A. Guglielmone, and S. Nava. 2017. Population dynamics of the cattle tick Rhipicephalus (Boophilus) microplus in a subtropical subhumid region of Argentina for use in the design of control strategies. Medical and Veterinary Entomology 311: 6-14.

Carreón, D., J. M. P. de la Lastra, C. Almazán, M. Canales, F. Ruiz-Fons, M. Boadella, J. A. MorenoCid, M. Villar, C. Gortázar, and M. Reglero. 2012. Vaccination with BM86, subolesin and akirin protective antigens for the control of tick infestations in white-tailed deer and red deer. Vaccine 302: 273-279. 
Coles, T. B., and M. W. Dryden. 2014. Insecticide/acaricide resistance in fleas and ticks infesting dogs and cats. Parasites \& Vectors 71: 8.

Connaway, J. W., and M. C. Francis. 1899. Texas fever. Experiments made by the Missouri Experiment Station and the Missouri State Board of Agriculture, in cooperation with the Texas Experiment Station in immunizing northern breeding cattle against Texas fever for the southern trade. Missouri Agricultural Experiment Station Bulletin 48: 1-66.

Costa-Júnior, L. M., R. J. Miller, P. B. Alves, A. F. Blank, A. Y. Li, and A. A. Pérez de León. 2016. Acaricidal efficacies of Lippia gracilis essential oil and its phytochemicals against organophosphateresistant and susceptible strains of Rhipicephalus (Boophilus) microplus. Veterinary Parasitology 228: 60-64.

Cuore, U., W. Acosta, F. Bermúdez, O. Da Silva, I. García, R. Pérez Rama, L. Luengo, A. Trelles, and M. A. Solari. 2015. Tick generational treatment: Implementation of a methodology to eradicate Rhipicephalus (Boophilus) microplus tick resistant to macrocyclic lactones in a population management. Veterinaria (Montevideo) 51: 14-25.

Currie, C. 2013. Influence of white-tailed deer on cattle fever tick eradication efforts in southern Texas. PhD dissertation. Texas A\&M University-Kingsville, Kingsville, Texas, USA.

Curtice, C. 1891. The biology of the cattle tick. Journal of Comparative Medical and Veterinary Archives 12: 313-319.

Curtice, C. 1910. Progress and prospects of tick eradication. US Department of Agriculture, Bureau of Animal Industry. Twenty-seventh Annual Report: 255-265.

Dantas-Torres, F. 2018. Species concepts: What about ticks? Trends in Parasitology 34(12): 1017-1026.

Dantas-Torres, F., B. B. Chomel, and D. Otranto. 2012. Ticks and tick-borne diseases: A One Health perspective. Trends in Parasitology 28: 437-446.

Davey, R. B., J. M. Pound, J. A. Klavons, K. H. Lohmeyer, J. M. Freeman, and P. U. Olafson. 2012. Analysis of doramectin in the serum of repeatedly treated pastured cattle used to predict the probability of cattle fever ticks (Acari: Ixodidae) feeding to repletion. Experimental and Applied Acarology 56: $365-374$.

Davidsson, M. 2018. The financial implications of a well-hidden and ignored chronic Lyme disease pandemic. Healthcare (Basel) 6: 16.

de Castro, J. J. 1997. Sustainable tick and tickborne disease control in livestock improvement in developing countries. Veterinary Parasitology 71: 77-97.

de la Fuente, J., K. Kocan, and M. Contreras. 2015a. Prevention and control strategies for ticks and pathogen transmission. Scientific and Technical Review 34: 249-264.

de la Fuente, J., A. Estrada-Peña, A. Cabezas-Cruz, and R. Brey. 2015b. Flying ticks: Anciently evolved associations that constitute a risk of infectious disease spread. Parasites \& Vectors 8: 538.

de la Fuente, J., M. Villar, A. Estrada-Peña, and J. A. Olivas. 2018. High throughput discovery and characterization of tick and pathogen vaccine protective antigens using vaccinomics with intelligent Big Data analytic techniques. Expert Review of Vaccines 17: 569-576.

de la Fuente, J., M. Rodríguez, M. Redondo, C. Montero, J. García-García, L. Méndez, E. Serrano, M. Valdés, A. Enriquez, and M. Canales. 1998. Field studies and cost-effectiveness analysis of vaccination with Gavac ${ }^{\mathrm{TM}}$ against the cattle tick Boophilus microplus. Vaccine 16: 366-373.

de la Fuente, J., C. Almazán, M. Canales, J. M. P. de la Lastra, K. M. Kocan, and P. Willadsen. 2007. A ten-year review of commercial vaccine performance for control of tick infestations on cattle. Animal Health Research Reviews 8: 23-28.

de Meneghi, D., F. Stachurski, and H. Adakal. 2016. Experiences in tick control by acaricide in the traditional cattle sector in Zambia and Burkina Faso: Possible environmental and public health implications. Frontiers in Public Health 4: 239.

de Miranda Santos, I. K., G. R. Garcia, P. S. Oliveira, C. J. Veríssimo, L. M. Katiki, L. Rodrigues, M. P. Szabó, and C. Maritz-Olivier. 2018. Acaricides: Current status and sustainable alternatives for controlling the cattle tick, Rhipicephalus microplus, based on its ecology, pp. 91-134. In C. Garros, J. Bouyer, W. Takken, and R. C. Smallegange (eds.), Pests and vector-borne diseases in the livestock industry. Wageningen Academic Publishers, Wageningen, The Netherlands. 
de Oliveira Filho, J. G., L. L. Ferreira, A. L. F. Sarria, J. A. Pickett, M. A. Birkett, G. M. Mascarin, A. A. Pérez de León, and L. M. F. Borges. 2017. Brown dog tick, Rhipicephalus sanguineus sensu lato, infestation of susceptible dog hosts is reduced by slow release of semiochemicals from a less susceptible host. Ticks and Tick-borne Diseases 8: 139-145.

de Oliveira Pascoal, J., S. M. de Siqueira, R. da Costa Maia, M. P. J. Szabó and J. Yokosawa. 2019. Detection and molecular characterization of Mogiana tick virus (MGTV) in Rhipicephalus microplus collected from cattle in a savannah area, Uberlândia, Brazil. Ticks and Tick-borne Diseases 101: 162165.

Drexler, N., M. Miller, J. Gerding, S. Todd, L. Adams, F. S. Dahlgren, N. Bryant, E. Weis, K. Herrick, J. Francies, K. Komatsu, S. Piontkowski, J. Velascosoltero, T. Shelhamer, B. Hamilton, C. Eribes, A. Brock, P. Sneezy, C. Goseyun, H. Bendle, R. Hovet, V. Williams, R. Massung, and J. H. McQuiston. 2014. Community-based control of the brown dog tick in a region with high rates of Rocky Mountain spotted fever, 2012-2013. PLoS One 912: e112368.

Egerton, F. N. 2013. History of ecological sciences, part 46: From parasitology to germ theory. The Bulletin of the Ecological Society of America 942: 136-164.

Eisen, R. J., and L. Eisen. 2018. The blacklegged tick, Ixodes scapularis: An increasing public health concern. Trends in Parasitology 344: 295-309.

Eisen, R. J., K. J. Kugeler, L. Eisen, C. B. Beard, and C. D. Paddock. 2017. Tick-borne zoonoses in the United States: Persistent and emerging threats to human health. ILAR Journal 58: 319-335.

(EMA) European Medicines Agency. 2018. Reflection paper on resistance in ectoparasites, Draft. EMA Committee for Medicinal Products for Veterinary Use, London, UK. 30 pp.

Esteve-Gassent, M. D., A. A. Pérez de León, D. Romero-Salas, T. P. Feria-Arroyo, R. Patino, I. Castro-Arellano, G. Gordillo-Pérez, A. Auclair, J. Goolsby, and R. I. Rodríguez-Vivas. 2014. Pathogenic landscape of transboundary zoonotic diseases in the Mexico-US border along the Rio Grande. Frontiers in Public Health 2: 177.

Esteve-Gassent, M. D., I. Castro-Arellano, T. P. Feria-Arroyo, R. Patino, A. Y. Li, R. F. Medina, A. A. Pérez de León, and R. I. Rodríguez-Vivas. 2016. Translating ecology, physiology, biochemistry, and population genetics research to meet the challenge of tick and tick-borne diseases in North America. Archives of Insect Biochemistry and Physiology 921: 38-64.

Estrada-Peña, A. 2015. Ticks as vectors: Taxonomy, biology and ecology. Scientific and Technical Review 34: 53-65.

Estrada-Peña, A., and M. Salman. 2013. Current limitations in the control and spread of ticks that affect livestock: A review. Agriculture 3: 221-235.

Estrada-Peña, A., D. Carreón, C. Almazán, and J. de la Fuente. 2014. Modeling the impact of climate and landscape on the efficacy of white-tailed deer vaccination for cattle tick control in northeastern Mexico. PLoS One 97: e102905.

Estrada-Peña, A., J. M. Venzal, S. Nava, A. Mangold, A. A. Guglielmone, M. B. Labruna, and J. de La Fuente. 2012. Reinstatement of Rhipicephalus (Boophilus) australis (Acari: Ixodidae) with redescription of the adult and larval stages. Journal of Medical Entomology 494: 794-802.

Évora, P. M., G. S. Sanches, F. D. Guerrero, A. Pérez de León, and G. H. Bechara. 2017. Immunogenic potential of Rhipicephalus (Boophilus) microplus aquaporin 1 against Rhipicephalus sanguineus in domestic dogs. Revista Brasileira de Parasitologia Veterinária 26: 60-66.

(FAO) Food and Agriculture Organization of the United Nations. 1961. The control of ticks on livestock. FAO Agricultural Studies No. 54. FAO, Rome, Italy.

Fernández, P. J., and W. R. White. 2016. Atlas of transboundary animal diseases, Second Edition. World Organisation for Animal Health (OIE), Paris, France.

Foil, L., P. Coleman, M. Eisler, H. Fragoso-Sanchez, Z. Garcia-Vazquez, F. Guerrero, N. Jonsson, I. Langstaff, A. Li, N. Machila, R. J. Miller, J. Morton, J. H. Pruett, and S. Torr. 2004. Factors that influence the prevalence of acaricide resistance and tick-borne diseases. Veterinary Parasitology 125: $163-181$.

Foley, A. M., J. A. Goolsby, A. Ortega-S Jr, J. A. Ortega-S, A. Pérez de León, N. K. Singh, A. Schwartz, D. Ellis, D. G. Hewitt, and T. A. Campbell. 2017. Movement patterns of nilgai antelope in South Texas: Implications for cattle fever tick management. Preventive Veterinary Medicine 146: $166-172$. 
Fouet, C., and C. Kamdem. 2019. Integrated mosquito management: Is precision control a luxury or necessity? Trends in Parasitology 35: 85-95.

Gaff, H. D., A. White, K. Leas, P. Kelman, J. C. Squire, D. L. Livingston, G. A. Sullivan, E. W. Baker, and D. E. Sonenshine. 2015. TickBot: A novel robotic device for controlling tick populations in the natural environment. Ticks and Tick-borne Diseases 6: 146-151.

Gasmi, S., C. Bouchard, N. H. Ogden, A. Adam-Poupart, Y. Pelcat, E. E. Rees, F. Milord, P. A. Leighton, R. L. Lindsay, and J. K. Koffi. 2018. Evidence for increasing densities and geographic ranges of tick species of public health significance other than Ixodes scapularis in Québec, Canada. PLoS One 138: e0201924.

George, J. E. 1989. Cattle fever tick eradication programme in the USA: History, achievements, problems and implications for other countries, pp. 1-7. In Proceedings Expert Consultation on the Eradication of Ticks with Special Reference to Latin America. FAO International Symposium, 22-26 June 1987, Mexico City, Mexico. FAO Animal Production and Health Paper 75, Rome, Italy.

George, J. E. 2000. Present and future technologies for tick control. Annals of the New York Academy of Sciences 916: 583-588.

George, J. E. 2008. The effects of global change on the threat of exotic arthropods and arthropod-borne pathogens to livestock in the United States. Annals of the New York Academy of Sciences 1149: 249254.

Ghosh, S. and G. Nagar. 2014. Problem of ticks and tick-borne diseases in India with special emphasis on progress in tick control research: A review. Journal of Vector Borne Diseases 51: 259-270.

Giles, J. R., A. T. Peterson, J. D. Busch, P. U. Olafson, G. A. Scoles, R. B. Davey, J. M. Pound, D. M. Kammlah, K. H. Lohmeyer, and D. M. Wagner. 2014. Invasive potential of cattle fever ticks in the southern United States. Parasites \& Vectors 71: 189.

Ginsberg, H. S., T. A. Bargar, M. L. Hladik, and C. Lubelczyk. 2017. Management of arthropod pathogen vectors in North America: Minimizing adverse effects on pollinators. Journal of Medical Entomology 54: 1463-1475.

González Sáenz Pardo, J., and R. Hernández Ortiz. 2012. Boophilus microplus: Current status of acaricide resistance on the Mexican American border and its impact on commerce. Revista Mexicana de Ciencias Pecuarias 3 (Supplement 1): 1-8.

Goolsby, J., J. Jung, J. Landivar, W. Mccutcheon, R. Lacewell, R. Duhaime, and A. Schwartz. 2016. Evaluation of Unmanned Aerial Vehicles (UAVs) for detection of cattle in the Cattle Fever Tick Permanent Quarantine Zone. Subtropical Agriculture and Environments 67: 24-27.

Goolsby, J. A., N. K. Singh, A. Ortega-S Jr, D. G. Hewitt, T. A. Campbell, D. Wester, and A. A. Pérez de León. 2017. Comparison of natural and artificial odor lures for nilgai (Boselaphus tragocamelus) and white-tailed deer (Odocoileus virginianus) in south Texas: Developing treatment for cattle fever tick eradication. International Journal for Parasitology: Parasites and Wildlife 62: 100-107.

Goolsby, J., N. Singh, D. Shapiro-Ilan, R. Miller, P. Moran, and A. Pérez de León. 2018. Treatment of cattle with Steinernema riobrave and Heterorhabditis floridensis for control of the southern cattle fever tick, Rhipicephalus (= Boophilus) microplus. Southwestern Entomologist 432: 295-301.

Gortazar, C., I. Diez-Delgado, J. A. Barasona, J. Vicente, J. de La Fuente, and M. Boadella. 2015. The wild side of disease control at the wildlife-livestock-human interface: A review. Frontiers in Veterinary Science 1: 27.

Graf, J.-F., R. Gogolewski, N. Leach-Bing, G. Sabatini, M. Molento, E. Bordin, and G. Arantes. 2004. Tick control: An industry point of view. Parasitology 129 (Supplement): S427-S442.

Graham, O., and J. Hourrigan. 1977. Eradication programs for the arthropod parasites of livestock. Journal of Medical Entomology 13: 629-658.

Gray, J. S., A. Estrada-Peña, and A. Zintl. 2019. Vectors of babesiosis. Annual Review of Entomology 64: $149-165$.

Gross, A. D., K. B. Temeyer, T. A. Day, A. A. Pérez de León, M. J. Kimber, and J. R. Coats. 2017. Interaction of plant essential oil terpenoids with the southern cattle tick tyramine receptor: A potential biopesticide target. Chemico-Biological Interactions 263: 1-6. 
Guerrero, F. D., R. Andreotti, K. G. Bendele, R. C. Cunha, R. J. Miller, K. Yeater, and A. A. Pérez de León. 2014a. Rhipicephalus (Boophilus) microplus aquaporin as an effective vaccine antigen to protect against cattle tick infestations. Parasites \& Vectors 71: 475.

Guerrero, F. D., A. A. Pérez de León, R. I. Rodríguez-Vivas, N. Jonsson, R. J. Miller, and R. Andreotti. 2014b. Acaricide research and development, resistance and resistance monitoring, pp. 353 381. In D. E. Sonenshine, and R. M. Roe (eds.), Biology of ticks, Volume 2. Oxford Unversity Press, New York, NY, USA.

Hansford, K. M., M. E. Pietzsch, B. Cull, E. L. Gillingham, and J. M. Medlock. 2018. Potential risk posed by the importation of ticks into the UK on animals: Records from the tick surveillance scheme. Veterinary Record 182: 107.

Harvey, E., K. Rose, J.-S. Eden, N. Lo, T. Abeyasuriya, M. Shi, S. L. Doggett, and E. C. Holmes. 2019. Extensive diversity of RNA viruses in Australian ticks. Journal of Virology 93: e01358-01318.

Hendrichs, J., M. Vreysen, A. Robinson, and P. Kenmore. 2007. Area-Wide Integrated Pest Management (AW-IPM): Principles, practice and prospects, pp. 3-33. In M. J. B. Vreysen, A. S. Robinson, and J. Hendrichs (eds.), Area-wide control of insect pests: From research to field implementation. Springer, Dordrecht, The Netherlands.

Henrioud, A. N. 2011. Towards sustainable parasite control practices in livestock production with emphasis in Latin America. Veterinary Parasitology 180: 2-11.

Heyman, P., C. Cochez, A. Hofhuis, J. Van Der Giessen, H. Sprong, S. R. Porter, B. Losson, C. Saegerman, O. Donoso-Mantke, and M. Niedrig. 2010. A clear and present danger: Tick-borne diseases in Europe. Expert Review of Anti-infective Therapy 8: 33-50.

Higgs, S. 2018. African swine fever - A call to action. Vector-Borne and Zoonotic Diseases 18: 509-510.

Hutcheson, H. J., L. R. Lindsay, and S. J. Dergousoff. 2019. Haemaphysalis longicornis: A tick of considerable importance, now established in North America. Canadian Journal of Public Health 110: 118-119.

(IAEA) International Atomic Energy Agency. 1968. Control of livestock insect pests by the Sterile-Male Technique. Proceedings of a panel, 23-27 January 1967, Vienna, Austria.

Jongejan, F., S. de Jong, T. Voskuilen, L. van den Heuvel, R. Bouman, H. Heesen, C. Ijzermans, and L. Berger. 2019. "Tekenscanner": A novel smartphone application for companion animal owners and veterinarians to engage in tick and tick-borne pathogen surveillance in the Netherlands. Parasites \& Vectors 12: 116.

Jonsson, N. N. 2004. Integrated control programs for ticks on cattle: An examination of some possible components. Food and Agriculture Organization of the United Nations Animal Production and Health Paper: $1-78$.

Jørs, E., A. Aramayo, O. Huici, F. Konradsen, and G. Gulis. 2017. Obstacles and opportunities for diffusion of Integrated Pest Management strategies reported by Bolivian small-scale farmers and agronomists. Environmental Health Insights 11: 1178630217703390.

Keesing, F., and R. S. Ostfeld. 2018. The tick project: Testing environmental methods of preventing tickborne diseases. Trends in Parasitology 34: 447-450.

Kerario, I. I., M. Simuunza, E. L. Laisser, and S. Chenyambuga. 2018. Exploring knowledge and management practices on ticks and tick-borne diseases among agro-pastoral communities in Southern Highlands, Tanzania. Veterinary World 11: 48-57.

Khamesipour, F., G. O. Dida, D. N. Anyona, S. M. Razavi, and E. Rakhshandehroo. 2018. Tick-borne zoonoses in the Order Rickettsiales and Legionellales in Iran: A systematic review. PLoS Neglected Tropical Diseases 12: e0006722.

Klafke, G., R. Miller, J. Tidwell, R. Barreto, F. Guerrero, P. Kaufman, and A. Pérez de León. 2017 a. Mutation in the sodium channel gene corresponds with phenotypic resistance of Rhipicephalus sanguineus sensu lato (Acari: Ixodidae) to pyrethroids. Journal of Medical Entomology 54: 1639-1642.

Klafke, G., A. Webster, B. D. Agnol, E. Pradel, J. Silva, L. H. de La Canal, M. Becker, M. F. Osório, M. Mansson, and R. Barreto. 2017b. Multiple resistance to acaricides in field populations of Rhipicephalus microplus from Rio Grande do Sul state, Southern Brazil. Ticks and Tick-borne Diseases 8: 73-80. 
Klassen, W. 1989. Eradication of introduced arthropod pests: Theory and historical practice. Miscellaneous Publications of the Entomological Society of America 73: 1-29.

Koul, O., G. W. Cuperus, and N. Elliott. 2008. Areawide pest management: Theory and implementation. CABI, Cambridge, Massachusetts, USA. 590 pp.

Laing, G., M. Aragrande, M. Canali, S. Savic, and D. de Meneghi. 2018. Control of cattle ticks and tick-borne diseases by acaricide in Southern Province of Zambia: A retrospective evaluation of animal health measures according to current One Health concepts. Frontiers in Public Health 6: 45.

Leal, B., D. B. Thomas, and R. K. Dearth. 2018. Population dynamics of off-host Rhipicephalus (Boophilus) microplus (Acari: Ixodidae) larvae in response to habitat and seasonality in south Texas. Veterinary Sciences 5: 33.

Lohmeyer, K. H., J. Pound, M. May, D. Kammlah, and R. Davey. 2011. Distribution of Rhipicephalus (Boophilus) microplus and Rhipicephalus (Boophilus) annulatus (Acari: Ixodidae) infestations detected in the United States along the Texas/Mexico border. Journal of Medical Entomology 48: 770 774.

Lohmeyer, K. H., J. M. Pound, J. A. Klavons, and R. Davey. 2013. Liquid chromatographic detection of permethrin from filter paper wipes of white-tailed deer. Journal of Entomological Science 48: 258 260.

Lohmeyer, K. H., M. A. May, D. B. Thomas, and A. A. Pérez de León. 2018. Implication of nilgai antelope (Artiodactyla: Bovidae) in reinfestations of Rhipicephalus (Boophilus) microplus (Acari: Ixodidae) in south Texas: A review and update. Journal of Medical Entomology 55: 515-522.

Lorusso, V., M. Wijnveld, A. O. Majekodunmi, C. Dongkum, A. Fajinmi, A. G. Dogo, M. Thrusfield, A. Mugenyi, E. Vaumourin, and A. C. Igweh. 2016. Tick-borne pathogens of zoonotic and veterinary importance in Nigerian cattle. Parasites \& Vectors 9: 217.

Magori, K. 2018. Preliminary prediction of the potential distribution and consequences of Haemaphysalis longicornis (Ixodida: Ixodidae) in the United States and North America, using a simple rule-based climate envelope model. bioRxiv: 389940.

Mans, B. J., D. De Klerk, R. Pienaar, and A. A. Latif. 2011. Nuttalliella namaqua: A living fossil and closest relative to the ancestral tick lineage: Implications for the evolution of blood-feeding in ticks. PLoS One 6: e23675.

Mans, B. J., J. Featherston, M. Kvas, K. A. Pillay, D. G. de Klerk, R. Pienaar, M. H. de Castro, T. G. Schwan, J. E. Lopez, P. Teel, A. A. Pérez de León, D. E. Sonenshine, N. I. Egekwu, D. K. Bakkes, H. Heyne, E. G. Kanduma, N. Nyangiwe, A. Bouattour, and A. A. Latif. 2019. Argasid and ixodid systematics: Implications for soft tick evolution and systematics, with a new argasid species list. Ticks and Tick-borne Diseases 10: 219-240.

Mansfield, K. L., L. Jizhou, L. P. Phipps, and N. Johnson. 2017. Emerging tick-borne viruses in the twenty-first century. Frontiers in Cellular and Infection Microbiology 7: 298.

McCosker, P. J. 1979. Global aspects of the management and control of ticks of veterinary importance, pp. 45-53. In J. G. Rodriguez (ed.), Recent advances in acarology, Volume II. Academic Press, New York, NY, USA.

McCosker, P. J. 1993. Ticks in a changing world. World Animal Review 74-75: 1-3.

McCoy, K. D., E. Léger, and M. Dietrich. 2013. Host specialization in ticks and transmission of tickborne diseases: A review. Frontiers in Cellular and Infection Microbiology 3: 57.

Mihajlović, J., J. Hovius, H. Sprong, P. Bogovič, M. Postma, and F. Strle. 2019. Cost-effectiveness of a potential anti-tick vaccine with combined protection against Lyme borreliosis and tick-borne encephalitis in Slovenia. Ticks and Tick-borne Diseases 10: 63-71.

Miller, R. J., R. B. Davey, and J. E. George. 2005. First report of organophosphate-resistant Boophilus microplus (Acari: Ixodidae) within the United States. Journal of Medical Entomology 42: 912-917.

Miller, R., A. Estrada-Peña, C. Almazán, A. Allen, L. Jory, K. Yeater, M. Messenger, D. Ellis, and A. A. Pérez de León. 2012. Exploring the use of an anti-tick vaccine as a tool for the integrated eradication of the cattle fever tick, Rhipicephalus (Boophilus) annulatus. Vaccine 30: 5682-5687. 
Miller, R. J., C. Almazán, M. Ortíz-Estrada, R. B. Davey, J. E. George, and A. Pérez de León. 2013. First report of fipronil resistance in Rhipicephalus (Boophilus) microplus of Mexico. Veterinary Parasitology 191: 97-101.

Minjauw, B., and A. McLeod. 2003. Tick-borne diseases and poverty: The impact of ticks and tick-borne diseases on the livelihoods of small-scale and marginal livestock owners in India and eastern and southern Africa. Department for International Development, Animal Health Programme, Centre for Tropical Veterinary Medicine, University of Edinburgh, UK.

Miraballes, C., and F. Riet-Correa. 2018. A review of the history of research and control of Rhipicephalus (Boophilus) microplus, babesiosis and anaplasmosis in Uruguay. Experimental and Applied Acarology 75: 383-398.

Mullens, B. A., N. C. Hinkle, R. Trout Fryxell, and K. Rochon. 2018. Past, present, and future contributions and needs for veterinary entomology in the United States and Canada. American Entomologist 64: 20-31.

Munoz, S., F. D. Guerrero, A. Kellogg, A. M. Heekin, and M.-Y. Leung. 2017. Bioinformatic prediction of $\mathrm{G}$ protein-coupled receptor encoding sequences from the transcriptome of the foreleg, including the Haller's organ, of the cattle tick, Rhipicephalus australis. PLoS One 12: e0172326.

Mutavi, F., N. Aarts, A. Van Paassen, I. Heitkönig, and B. Wieland. 2018. Techne meets metis: Knowledge and practices for tick control in Laikipia County, Kenya. NJAS - Wageningen Journal of Life Sciences 86-87: 136-145.

Narladkar, B. 2018. Projected economic losses due to vector and vector-borne parasitic diseases in livestock of India and its significance in implementing the concept of integrated practices for vector management. Veterinary World 11: 151-160.

Needham, G. R., and P. D. Teel. 1991. Off-host physiological ecology of ixodid ticks. Annual Review of Entomology 36: 659-681.

Nieto, N. C., W. T. Porter, J. C. Wachara, T. J. Lowrey, L. Martin, P. J. Motyka, and D. J. Salkeld. 2018. Using citizen science to describe the prevalence and distribution of tick bite and exposure to tickborne diseases in the United States. PLoS One 13: e0199644.

Ntondini, Z., E. Van Dalen, and I. G. Horak. 2008. The extent of acaricide resistance in 1-, 2-and 3-host ticks on communally grazed cattle in the eastern region of the Eastern Cape Province, South Africa. Journal of the South African Veterinary Association 79: 130-135.

Ogden, N. H., and L. R. Lindsay. 2016. Effects of climate and climate change on vectors and vectorborne diseases: Ticks are different. Trends in Parasitology 32: 646-656.

Ojeda-Chi, M. M., R. I. Rodríguez-Vivas, M. D. Esteve-Gassent, A. A. Pérez de León, J. J. Modarelli, and S. L. Villegas-Pérez. 2019. Ticks infesting dogs in rural communities of Yucatan, Mexico and molecular diagnosis of rickettsial infection. Transboundary and Emerging Diseases 66: 102-110.

Olafson, P. U., D. B. Thomas, M. A. May, B. G. Buckmeier, and R. A. Duhaime. 2018. Tick vector and disease pathogen surveillance of nilgai antelope, Boselaphus tragocamelus, in southeastern Texas, USA. Journal of Wildlife Diseases 54: 734-744.

Paddock, C. D., R. S. Lane, J. E. Staples, and M. B. Labruna. 2016. Appendix 8: Changing paradigms for tick-borne diseases in the Americas, pp. 221-258. In Global health impacts of vector-borne diseases: Workshop summary. Forum on Microbial Threats, National Academies of Sciences, Engineering, and Medicine, 16-17 September 2014, Washington, DC, USA. National Academies Press, Washington, DC, USA.

Pegram, R. G., D. D. Wilson, and J. W. Hansen. 2000. Past and present national tick control programs: Why they succeed or fail. Annals of the New York Academy of Sciences 916: 546-554.

Pegram, R., A. Wilsmore, C. Lockhart, R. Pacer, and C. Eddi. 2007. The Carribean Amblyomma variegatum eradication programme: Success or failure? pp. 709-720. In M. J. B. Vreysen, A. S. Robinson, and J. Hendrichs (eds.), Area-wide control of insect pests: From research to field implementation. Springer, Dordrecht, The Netherlands.

Peñalver, E., A. Arillo, X. Delclòs, D. Peris, D. A. Grimaldi, S. R. Anderson, P. C. Nascimbene, and R. Pérez-de la Fuente. 2018. Ticks parasitised feathered dinosaurs as revealed by Cretaceous amber assemblages. Nature Communications 9: 472. 
Pérez de León, A. A. 2017. Integrated Tick Management: Challenges and opportunities to mitigate tickborne disease burden. Revista Colombiana de Ciencias Pecuarias 30 (Supplement): 280-285.

Pérez de León, A. A., D. A. Strickman, D. P. Knowles, D. Fish, E. Thacker, J. de la Fuente, P. J. Krause, S. K. Wikel, R. S. Miller and G. G. Wagner, C. Almazán, R. Hillman, M. T. Messenger, P. O. Ugstad, R. A. Duhaime, P.D. Teel, A. Ortega-Santos, D. G. Hewitt, E. J. Bowers, S. J. Bent, M. H. Cochran, T. F. McElwain, G. A. Scoles, C. E. Suarez, R. Davey, J. M. Howell Freeman, K. Lohmeyer K, A. Y. Li, F. D. Guerrero, D. M. Kammlah, P. Phillips, J. M. Pound, and the Group for Emerging Babesioses and One Health Research and Development in the U.S. 2010. One Health approach to identify research needs in bovine and human babesioses: Workshop report. Parasites \& Vectors 3: 36.

Pérez de León, A. A., P. D. Teel, A. N. Auclair, M. T. Messenger, F. D. Guerrero, G. Schuster, and R. J. Miller. 2012. Integrated strategy for sustainable cattle fever tick eradication in USA is required to mitigate the impact of global change. Frontiers in Physiology 3: 195.

Pérez de León, A. A., R. I. Rodríguez-Vivas, F. D. Guerrero, Z. García-Vázquez, K. B. Temeyer, D. I. Domínguez-García, A. Li, N. Cespedes, R. J. Miller, and R. Rosario Cruz. 2013. Acaricide resistance in Rhipicephalus (Boophilus) microplus: Impact on agro-biosecurity and cattle trade between Mexico and the United States of America, pp. 18-35. In D. I. Domínguez-García, R. Rosario Cruz, and M. Ortiz Estrada (eds.), Proceeedings 3th International Symposium on Pesticide Resistance in Arthropods: Integrated Cattle Tick and Fly Control and Mitigation of Pesticide Resistance, 24 June 2013, Ixtapa, Zihuatanejo, Mexico. Universidad Autónoma de Guerrero Press, Chilpancingo, Guerrero, Mexico.

Pérez de León, A. A., P. D. Teel, A. Li, L. Ponnusamy, and R. M. Roe. 2014a. Advancing Integrated Tick Management to mitigate burden of tick-borne diseases. Outlooks on Pest Management 256: 382 389.

Pérez de León, A. A., E. Vannier, C. Almazán, and P. J. Krause. 2014b. Tick-borne protozoa, pp. 147179. In D. E. Sonenshine and R. M. Roe (eds.), Biology of ticks, Volume 2. Oxford Unversity Press, New York, NY, USA.

Pérez de León, A. A., S. Mahan, M. Messenger, D. Ellis, K. Varner, A. Schwartz, D. Baca, R. Andreotti, M. R. Valle, R. R. Cruz, D. I. Domínguez García, M. Comas Pagan, C. Oliver Canabal, J. Urdaz, F. Collazo Mattei, F. Soltero, F. Guerrero, and R. J. Miller. 2018. Public-private partnership enabled use of anti-tick vaccine for integrated cattle fever tick eradication in the USA, pp. 275-298. In C. Garros, J. Bouyer, W. Takken, and R. C. Smallegange (eds.), Pests and vector-borne diseases in the livestock industry. Wageningen Academic Publishers, Wageningen, The Netherlands.

Perry, B. 2016. The control of East Coast fever of cattle by live parasite vaccination: A science-to-impact narrative. One Health 2: 103-114.

Petersen, L. R., C. B. Beard, and S. N. Visser. 2019. Combatting the increasing threat of vector-borne disease in the United States with a national vector-borne disease prevention and control system. American Journal of Tropical Medicine and Hygiene 100: 242-245.

Pfister, K., and R. Armstrong. 2016. Systemically and cutaneously distributed ectoparasiticides: A review of the efficacy against ticks and fleas on dogs. Parasites \& Vectors 9: 436.

Phillips, P. L., J. B. Welch, and M. Kramer. 2014. Development of a spatially targeted field sampling technique for the southern cattle tick, Rhipicephalus microplus, by mapping white-tailed deer, Odocoileus virginianus, habitat in south Texas. Journal of Insect Science 14 (88): 1-21.

Piesman, J., and L. Eisen. 2008. Prevention of tick-borne diseases. Annual Review of Entomology 53: 323-343.

Playford, M., A. R. Rabiee, I. J. Lean, and M. Ritchie. 2005. Review of research needs for cattle tick control, Phases I and II. Meat \& Livestock Australia Ltd., Sydney, Australia.

Pluess, T., R. Cannon, V. Jarošík, J. Pergl, P. Pyšek, and S. Bacher. 2012. When are eradication campaigns successful? A test of common assumptions. Biological Invasions 14: 1365-1378.

Pollett, S., B. M. Althouse, B. Forshey, G. W. Rutherford, and R. G. Jarman. 2017. Internet-based biosurveillance methods for vector-borne diseases: Are they novel public health tools or just novelties? PLoS Neglected Tropical Diseases 11: e0005871. 
Pound, J., J. George, D. Kammlah, K. Lohmeyer, and R. Davey. 2010. Evidence for role of white-tailed deer (Artiodactyla: Cervidae) in epizootiology of cattle ticks and southern cattle ticks (Acari: Ixodidae) in reinfestations along the Texas/Mexico border in south Texas: A review and update. Journal of Economic Entomology 103: 211-218.

Pound, J. M., K. H. Lohmeyer, R. B. Davey, L. A. Soliz, and P. U. Olafson. 2012. Excluding feral swine, javelinas, and raccoons from deer bait stations. Human - Wildlife Interactions 6: 169-177.

Pruneau, L., K. Lebrigand, B. Mari, T. Lefrancois, D. F. Meyer, and N. Vachiery. 2018. Comparative transcriptome profiling of virulent and attenuated Ehrlichia ruminantium strains highlighted strong regulation of map 1- and metabolism related genes. Frontiers in Cellular and Infection Microbiology 8: 153.

Rainey, T., J. L. Occi, R. G. Robbins, and A. Egizi. 2018. Discovery of Haemaphysalis longicornis (Ixodida: Ixodidae) parasitizing a sheep in New Jersey, United States. Journal of Medical Entomology 55: 757-759.

Rasi, T., I. Majlath, M. Bogdziewicz, K. Dudek, V. Majlathova, J. Wlodarek, M. Almasi, B. Vargova, and P. Tryjanowski. 2018. Tick distribution along animal tracks: Implication for preventative medicine. Annals of Agricultural and Environmental Medicine 25: 360-363.

Redondo, M., H. Fragoso, C. Montero, J. Lona, J. A. Medellín, R. Fría, V. Hernández, R. Franco, H. Machado, and M. Rodríguez. 1999. Integrated control of acaricide-resistant Boophilus microplus populations on grazing cattle in Mexico using vaccination with Gavac ${ }^{\mathrm{TM}}$ and amidine treatments. Experimental and Applied Acarology 23: 841-849.

Reece, L. M., D. W. Beasley, G. N. Milligan, V. V. Sarathy, and A. D. Barrett. 2018. Current status of Severe Fever with Thrombocytopenia Syndrome vaccine development. Current Opinion in Virology 29: 72-78.

Riccardi, N., R. M. Antonello, R. Luzzati, J. Zajkowska, S. Di Bella, and D. R. Giacobbe. 2019. Tickborne encephalitis in Europe: A brief update on epidemiology, diagnosis, prevention, and treatment. European Journal of Internal Medicine 62: 1-6.

Robles, N. J. C., H. J. Han, S.-J. Park, and Y. K. Choi. 2018. Epidemiology of severe fever and thrombocytopenia syndrome virus infection and the need for therapeutics for the prevention. Clinical and Experimental Vaccine Research 7: 43-50.

Rochlin, I. 2019. Modeling the Asian longhorned tick (Acari: Ixodidae) suitable habitat in North America. Journal of Medical Entomology 56: 384-391.

Rodríguez-Mallon, A., J. L. C. Anadón, A. A. L. Pérez, G. H. Bechara, R. Z. Machado, R. L. Cruz, A. Domingos, and A. R. T. Sosa. 2018. CYTED Network to develop an immunogen compatible with integrated management strategies for tick control in cattle. Vaccine 36: 6581-6586.

Rodríguez-Vivas, R. I., N. N. Jonsson, and C. Bhushan. 2018. Strategies for the control of Rhipicephalus microplus ticks in a world of conventional acaricide and macrocyclic lactone resistance. Parasitology Research 117: 3-29.

Rodríguez-Vivas, R. I., L. Grisi, A. A. Pérez de León, H. Silva Villela, J. F. d. J. Torres-Acosta, H. Fragoso Sánchez, D. Romero Salas, R. Rosario Cruz, F. Saldierna, and D. García Carrasco. 2017a. Potential economic impact assessment for cattle parasites in Mexico. Review. Revista Mexicana de Ciencias Pecuarias 8: 61-74.

Rodríguez-Vivas, R. I., M. M. Ojeda-Chi, I. Trinidad-Martinez, and A. A. Pérez de León. 2017b. First documentation of ivermectin resistance in Rhipicephalus sanguineus sensu lato (Acari: Ixodidae). Veterinary Parasitology 233: 9-13.

Rosenberg, R., N. P. Lindsey, M. Fischer, C. J. Gregory, A. F. Hinckley, P. S. Mead, G. Paz-Bailey, S. H. Waterman, N. A. Drexler, G. J. Kersh, H. Hooks, S. K. Partridge, S. N. Visser, C. B. Beard, and L. R. Petersen. 2018. Vital signs: Trends in reported vectorborne disease cases-United States and territories, 2004-2016. Morbidity and Mortality Weekly Report 67: 496-501.

Roy, B. C., A. Estrada-Peña, J. Krücken, A. Rehman, and A. M. Nijhof. 2018. Morphological and phylogenetic analyses of Rhipicephalus microplus ticks from Bangladesh, Pakistan and Myanmar. Ticks and Tick-borne Diseases 9: 1069-1079.

Rushton, J. 2009. The economics of animal health and production. CABI, Cambridge, Massachusetts, USA. 384 pp. 
Rutherford, B. 2019. A long, thin line. Beef Magazine. December 4, 20-19.

Sakamoto, J. M. 2018. Progress, challenges, and the role of public engagement to improve tick-borne disease literacy. Current Opinion in Insect Science 28: 81-89.

Scasta, J. D. 2015. Livestock parasite management on high-elevation rangelands: Ecological interactions of climate, habitat, and wildlife. Journal of Integrated Pest Management 6: 8.

Schetters, T., R. Bishop, M. Crampton, P. Kopáček, A. Lew-Tabor, C. Maritz-Olivier, R. Miller, J. Mosqueda, J. Patarroyo, and M. Rodriguez-Valle. 2016. Cattle tick vaccine researchers join forces in CATVAC. Parasites \& Vectors 9: 105.

Schmidtmann, E. T. 1994. Ecologically based strategies for controlling ticks, pp. 240-280. In D. E. Sonenshine, and T. N. Mather (eds.), Ecological dynamics of tick-borne zoonoses. Oxford University Press, New York, NY, USA.

Schultz, M. 2008. Theobald Smith. Emerging Infectious Diseases 14: 1940-1942.

Shepard, D. S., Y. A. Halasa, D. M. Fonseca, A. Farajollahi, S. P. Healy, R. Gaugler, K. BartlettHealy, D. A. Strickman, and G. G. Clark. 2014. Economic evaluation of an Area-Wide Integrated Pest Management program to control the Asian tiger mosquito in New Jersey. PLoS One 9: e111014.

Singer, M., and N. Bulled. 2016. Ectoparasitic syndemics: Polymicrobial tick-borne disease interactions in a changing anthropogenic landscape. Medical Anthropology Quarterly 30: 442-461.

Singh, N. K., J. A. Goolsby, A. Ortega-S Jr, D. G. Hewitt, T. A. Campbell, and A. Pérez de León. 2017. Comparative daily activity patterns of Nilgai, Boselaphus tragocamelus and white-tailed deer, Odocoileus virginianus in South Texas. Subtropical Agriculture and Environments 68: 7-12.

Singh, N. K., R. J. Miller, G. M. Klafke, J. A. Goolsby, D. B. Thomas, and A. A. Pérez de León. 2018. In-vitro efficacy of a botanical acaricide and its active ingredients against larvae of susceptible and acaricide-resistant strains of Rhipicephalus (Boophilus) microplus Canestrini (Acari: Ixodidae). Ticks and Tick-borne Diseases 9: 201-206.

Šmit, R., and M. J. Postma. 2016. Vaccines for tick-borne diseases and cost-effectiveness of vaccination: A public health challenge to reduce the diseases' burden. Expert Review of Vaccines 15: 5-7.

Smith, T., and F. L. Kilborne. 1893. Investigations into the nature, causation, and prevention of Texas or southern cattle fever. US Department of Agriculture, Bureau of Animal Industry Bulletin 1: 1-301.

Socolovschi, C., B. Doudier, F. Pages, and P. Parola. 2008. Tiques et maladies transmises a l'homme en Afrique. Médecine Tropicale 68: 119-133.

Sonenshine, D. E. 2018. Range expansion of tick disease vectors in North America: Implications for spread of tick-borne disease. International Journal of Environmental Research and Public Health 15: 478.

Sonenshine, D. E., and R. M. Roe (eds.). 2014. Biology of ticks. Second Edition, Volumes 1 and 2. Oxford University Press, New York, NY, USA. 560 pp. and 496 pp.

Souza, W. M., M. J. Fumagalli, A. O. Torres Carrasco, M. F. Romeiro, S. Modha, M. C. Seki, J. M. Gheller, S. Daffre, M. R. T. Nunes, P. R. Murcia, G. O. Acrani, and L. T. M. Figueiredo. 2018. Viral diversity of Rhipicephalus microplus parasitizing cattle in southern Brazil. Scientific Reports 8: 16315.

Spengler, J. R., D. A. Bente, M. Bray, F. Burt, R. Hewson, G. Korukluoglu, A. Mirazimi, F. Weber, and A. Papa. 2018. Meeting report: Second International Conference on Crimean-Congo Hemorrhagic Fever. Antiviral Research 150: 137-147.

Sprong, H., J. Trentelman, I. Seemann, L. Grubhoffer, R. O. Rego, O. Hajdušek, P. Kopáček, R. Šíma, A. M. Nijhof, and J. Anguita. 2014. ANTIDotE: Anti-tick vaccines to prevent tick-borne diseases in Europe. Parasites \& Vectors 7: 77.

Stafford III, K. C., S. C. Williams, and G. Molaei. 2017. Integrated Pest Management in controlling ticks and tick-associated diseases. Journal of Integrated Pest Management 8: 28.

Strom, C. 2010. Making catfish bait out of government boys: The fight against cattle ticks and the transformation of the yeoman South. University of Georgia Press, Athens, Georgia, USA. 197 pp. 
Suarez, M., J. Rubi, D. Pérez, V. Cordova, Y. Salazar, A. Vielma, F. Barrios, C. A. Gil, N. Segura, Y. Carrillo, R. Cartaya, M. Palacios, E. Rubio, C. Escalona, C. Ramirez, R. Basulto Baker, H. Machado, Y. Sordo, J. Bermudes, M. Vargas, C. Montero, A. Cruz, P. Puente, J. L. Rodriguez, E. Mantilla, O. Oliva, E. Smith, A. Castillo, B. Ramos, Y. Ramirez, Z. Abad, A. Morales, E. M. Gonzalez, A. Hernandez, Y. Ceballo, D. Callard, A. Cardoso, M. Navarro, J. L. Gonzalez, R. Pina, M. Cueto, C. Borroto, E. Pimentel, Y. Carpio, and M. P. Estrada. 2016. High impact and effectiveness of Gavac ${ }^{\mathrm{TM}}$ vaccine in the national program for control of bovine ticks Rhipicephalus microplus in Venezuela. Livestock Science 187: 48-52.

Suarez, C. E., H. F. Alzan, M. G. Silva, V. Rathinasamy, W. A. Poole, and B. M. Cooke. 2019. Unravelling the cellular and molecular pathogenesis of bovine babesiosis: Is the sky the limit? International Journal for Parasitology 49: 183-197.

Suckling, D. M., L. D. Stringer, A. E. Stephens, B. Woods, D. G. Williams, G. Baker, and A. M. EISayed. 2014. From Integrated Pest Management to integrated pest eradication: Technologies and future needs. Pest Management Science 70: 179-189.

Sungirai, M., S. Baron, N. A. Van der Merwe, D. Z. Moyo, P. De Clercq, C. Maritz-Olivier, and M. Madder. 2018. Population structure and genetic diversity of Rhipicephalus microplus in Zimbabwe. Acta Tropica 180: 42-46.

Sutherst, R., G. F. Maywald, and A. S. Bourne. 2007. Including species interactions in risk assessments for global change. Global Change Biology 13: 1843-1859.

Talactac, M. R., E. P. Hernandez, K. Fujisaki, and T. Tanaka. 2018. A continuing exploration of tickvirus interactions using various experimental viral infections of hard ticks. Frontiers in Physiology 9: 1728.

Tatchell, R. 1992. Ecology in relation to Integrated Tick Management. International Journal of Tropical Insect Science 13: 551-561.

Telford, S. R. 2017. Deer reduction is a cornerstone of integrated deer tick management. Journal of Integrated Pest Management 8: 25.

Theobald, S., N. Brandes, M. Gyapong, S. El-Saharty, E. Proctor, T. Diaz, S. Wanji, S. Elloker, J. Raven, and H. Elsey. 2018. Implementation research: New imperatives and opportunities in global health. The Lancet 392: 2214-2228.

Thomas, D., J. Tidwell, and A. Pérez de León. 2017. In vitro efficacy testing of a commercial formulation of the acaropathogenic fungus Metarhizium brunneum Petch (Hypocreales: Clavicipitaceae) strain F52 against the southern cattle fever tick Boophilus microplus Canestrini (Acari: Ixodidae). Subtropical Agriculture and Environments 68: 1-6.

Urdaz-Rodríguez, J., R. Miller, P. Teel, I. Castro-Arellano, F. Guerrero, M. T. Messenger, F. Soltero, W. E. Grant, H.-H. Wang, C. Oliver-Canabal, M. Comas-Pagan, and A. Pérez de León. 2015. Integrated Tick Management to mitigate the impact of Rhipicephalus microplus, bovine anaplasmosis, and bovine babesiosis in livestock farming systems in Puerto Rico, pp. 619. In Proceedings 14th Symposium of the International Society for Veterinary Epidemiology and Economics. International Symposium on Veterinary Epidemiology and Economics, 3-7 November 2015, Mérida, Mexico.

(USHHS) United States Health and Human Services. 2018. Tick-Borne Disease Working Group 2018 Report to Congress. Washington, DC, USA.

Uspensky, I. 2008. Argasid (soft) ticks (Acari: Ixodida: Argasidae), pp. 283-288. In J. L. Capinera (ed.), Encyclopedia of entomology. Springer. Dordrecht, The Netherlands.

Valle, M. R., L. Mèndez, M. Valdez, M. Redondo, C. M. Espinosa, M. Vargas, R. L. Cruz, H. P. Barrios, G. Seoane, and E. S. Ramirez. 2004. Integrated control of Boophilus microplus ticks in Cuba based on vaccination with the anti-tick vaccine Gavac. Experimental and Applied Acarology 34: 375 382 .

Vayssier-Taussat, M., J. F. Cosson, B. Degeilh, M. Eloit, A. Fontanet, S. Moutailler, D. Raoult, E. Sellal, M.-N. Ungeheuer, and P. Zylbermann. 2015. How a multidisciplinary 'One Health' approach can combat the tick-borne pathogen threat in Europe. Future Microbiology 10: 809-818.

Vudriko, P., J. Okwee-Acai, J. Byaruhanga, D. S. Tayebwa, R. Omara, J. B. Muhindo, C. Lagu, R. Umemiya-Shirafuji, X. Xuan, and H. Suzuki. 2018. Evidence-based tick acaricide resistance intervention strategy in Uganda: Concept and feedback of farmers and stakeholders. Ticks and Tickborne Diseases 9: 254-265.

Walker, A. R. 2011. Eradication and control of livestock ticks: Biological, economic and social perspectives. Parasitology 138: 945-959. 
Wang, H.-H., M. S. Corson, W. E. Grant, and P. D. Teel. 2017. Quantitative models of Rhipicephalus (Boophilus) ticks: Historical review and synthesis. Ecosphere 8: e01942.

Wang, H.-H., R. J. Miller, A. Pérez de León, and P. D. Teel. 2019. Simulation tools for assessment of tick suppression treatments of the southern cattle fever tick, Rhipicephalus (Boophilus) microplus, on non-lactating dairy cattle in Puerto Rico. Parasites \& Vectors 12: 185.

Wang, H.-H., P. D. Teel, W. E. Grant, G. Schuster, and A. Pérez de León. 2016. Simulated interactions of white-tailed deer (Odocoileus virginianus), climate variation and habitat heterogeneity on southern cattle tick (Rhipicephalus (Boophilus) microplus) eradication methods in south Texas, USA. Ecological Modelling 342: 82-96.

Wang, Y., K. Li, P. Li, J. Sun, L. Ye, Y. Dai, A. Tang, J. Jiang, C. Chen, Z. Tong, and J. Yan. 2018. Community-based comprehensive measures to prevent severe fever with thrombocytopenia syndrome, China. International Journal of Infectious Diseases 73: 63-66.

Whalon, M. E., D. Mota-Sanchez, and R. M. Hollingworth. 2008. Global pesticide resistance in arthropods. CABI, Cambridge, Massachusetts, USA.

White, A., and H. Gaff. 2018. Application of tick control technologies for blacklegged, lone star, and American dog ticks. Journal of Integrated Pest Management 9: 12.

(WHO) World Health Organization of the United Nations. 2017. Global vector control response 2017 2030. Geneva, Switzerland. Licence: CC BY-NC-SA 3.0 IGO.

Wikel, S. 2018. Ticks and tick-borne infections: Complex ecology, agents, and host interactions. Veterinary Sciences 5: 60 .

Willadsen, P. 2008. Anti-tick vaccines, pp. 424-446. In A. S. Bowman, and P. Nuttal (eds.), Ticks: Biology, disease, and control. Cambridge University Press, New York, NY, USA.

Williams, S. C., K. C. Stafford III, G. Molaei, and M. A. Linske. 2018. Integrated control of nymphal Ixodes scapularis: Effectiveness of white-tailed deer reduction, the entomopathogenic fungus Metarhizium anisopliae, and fipronil-based rodent bait boxes. Vector-Borne and Zoonotic Diseases 18: $55-64$.

World Bank. 2018. One Health: Operational framework for strengthening human, animal, and environmental public health systems at their interface. Working paper, report number 122980. Washington, DC, USA.

Ybañez, A. P., C. N. Mingala, and R. H. D. Ybañez. 2018. Historical review and insights on the livestock tick-borne disease research of a developing country: The Philippine scenario. Parasitology International 67: 262-266. 